Dapat diakses pada: http://jkb.ub.ac.id/index.php/jkb/article/view/2550

Jurnal Kedokteran Brawijaya Vol. 30, No. 4, Agustus 2019, pp. 253-258

Article History: Received 21 Maret 2019, Accepted 9 Agustus 2019

Artikel Penelitian

\title{
Aktivitas Sitotoksik Fraksi Heksana Terung Pokak (Solanum torvum) terhadap Sel Kanker T47D
}

\section{Cytotoxic Activity of Hexane Fraction of Solanium torvum on Cancer Cells T47D}

\author{
Nunuk Helilusiatiningsih', Yunianta', Harijono ${ }^{2}$, Simon Bambang $W^{2}$, Hidayat Sujuti ${ }^{3}$ \\ ${ }^{1}$ Departemen Agroteknologi Fakultas Pertanian Universitas Islam Kadiri Kediri \\ ${ }^{2}$ Departemen Teknologi Hasil Pertanian Fakultas Teknologi Pertanian Universitas Brawijaya Malang \\ ${ }^{3}$ Departemen Biokimia Biomolekuler Fakultas Kedokteran Universitas Brawijaya Malang
}

\begin{abstract}
ABSTRAK
Terung pokak adalah tanaman dari genus Solanum yang diperkirakan memiliki sifat antikanker. Tujuan penelitian ini menganalisis kandungan dan aktivitas sitotoksik fraksi heksana terung pokak terhadap sel kanker T47D secara invitro. Uji identifikasi senyawa pada fraksi heksana terung pokak menggunakan uji kualitatif dengan penapisan fitokimia dan (Gas Chromatography-Mass Spectometry), uji sitotoksik menggunakan metode MTT, uji siklus sel kanker T47D dan apoptosis menggunakan metode flowcytometry. Hasil uji fitokimia menunjukkan terung pokak mengandung alkaloid, saponin, glikosida dan steroid. Hasil uji identifikasi kimia fraksi heksana terung pokak menunjukkan 29 komponen yaitu asam asetat, asam propionat, 2- pentenal, 2- metilfuran, 1- penten-3-on, asam butirat, 2 -metilbutan, 2,3 butanedion, dimetil disuksipirazin, Ifida, asam valerat, furfural, 3- heksanon, metional, heksanal, benzaldehid, 2-heptenal, 4- heptenal, 1,5 octadien 3-on, 2- butilfuran, 3,5- oktadien-2- on, 1 okten-3-on, 2-pentilfuran, 2,6-nonadienal, 2- nonenal, 2- Isopropil-3metoksipirazin, linalool, 2- isobutil metoksipirazin, dekalakton. Fraksi heksana terung pokak bersifat sitotoksik terhadap sel kanker T47D dengan IC ${ }_{50}$ sebesar $85,58 \mu \mathrm{g} / \mathrm{mL}$. Fraksi heksana terung pokak dapat menghambat siklus sel T47D pada fase G0-G1 sebesar 35,84\%, fase S 27,05\%, fase G2-M 37,46\% dari pengamatan 20.000 sel T47D . Fraksi heksana terung pokak dapat memacu apoptosis awal sebesar 28,89\% dan apoptosis akhir 1,04\% dari pengamatan 20.000 sel T47D. Hasil tersebut menunjukkan bahwa fraksi heksana terung pokak bersifat sitotoksik, menghambat proliferasi dan memacu apoptosis sel T47D, sehingga layak dikembangkan sebagai antikanker.
\end{abstract}

Kata Kunci: Heksana, sitotoksik, Solanum torvum, T47D

\begin{abstract}
Solanum torvum is thought to possess anticancer antivity. The present study aimed to identify compounds of and analyse cytotoxic activity of the Solanum torvum hexane fraction T47D cancer cells in vitro. Identification of chemical compounds of Solanum torvum hexane fraction was performed by qualitative phytochemical screening and Gas ChromatographyMass Spectrometry cytotoxic assay employing MTT, cell cycle and apoptosis by using flowcytometry. The results showed that the extract contained alkaloids, saponins, glycosides, and steroids. Chemicals identified were twenty nine i.e. acetic acid, propionic acid, 2- pentenal, 2- methylfuran, 1- penten- 3- one, butiryc acid, 2- methyl-butanan, 2,3 -butanedione, Dimethyl- disuxypyrazine, ifidde, valeric acid, furfural, 3- hexanone, methional, hexanal, benzaldehyde, 2- heptenal, 4 heptenal, 1,5- octadien-3- one, 2- butylfuran, 3,5- octadien -2-one, 1- octen-3 one, 2- penthylfuran, 2,6- nonadienal, 2nonenal, 2-isopropyl-3-methoxypyrazine, linalool, 2-isobutyl methoxypyrazine and decalacton. Cytotoxic assays showed that the extract $I C_{50}$ was $85.58 \mu \mathrm{g} / \mathrm{mL}$. The extract inhibited cell proliferation at phase G0-G1 35.84\%, S-phase 27.05\% , G2-M 37.46\% of total 20,000 T47D cells. Solanum torvum hexane fraction induced early apoptosis on $28.89 \%$ and apoptosis of 1.04\% T47D cells. The results clarified that the cytotoxic properties of Solanum torvum hexane fraction inhibits T47D cancer cells proliferation and induces apoptosis, thus potentially developed as anticancer.
\end{abstract}

Keywords: Cytotoxic, hexane, Solanium torvum, T47D

Korespondensi: Nunuk Helilusiatiningsih. Departemen Agroteknologi Fakultas Pertanian Universitas Islam Kadiri Kediri, Jl. Sersan Suharmaji No.38, Manisrenggo, Kec. Kota Kediri, Kediri, Jawa Timur64128 Tel.08125268584 Email: nunukhelilusi@gmail.com 


\section{PENDAHULUAN}

Tanaman terung pokak (Solanum torvum) memiliki senyawa kimia seperti neoklorogenin 6-O- $\beta$-D-kuinovopiranosid, neokhlorogenin 6-O- $\beta$-D-silopiranosil-( $1 \rightarrow 3)$ $\beta$-D-kuinovopiranosid ,6-O- $\alpha$-L-ramnopiranosil-(1 $\rightarrow 3)$-D beta kuinovopiranosid, solagenin 6-O- $\beta$-Dkuinovopiranosid, solagenin 6-O- $\alpha$-L-ramnopiranosil $(1 \rightarrow 3)$ - $\beta$-D-kuinovopiranosid, isokue-rsetin, rutin, kaemferol dan kuersetin (1). Ekstrak etanol buah kering Solanum torvum mengandung fruktosa, glukosa, trigliserida dan insulin (2). Buah Solanum torvum mengandung solasonin, solamargin, steroid yang berfungsi pada sistem neuron dan gastrointestinal (3). Metil kafeat yang diekstrak dari buah Solanum torvum berfungsi sebagai anti kanker (4). Ekstrak eter buah kering Solanum torvum mengandung steroid, saponin, terpenoid, tanin, alkoloid, besi, asam lemak, asam askorbat (5).

Terung pokak (Solanum torvum) di Indonesia masih tergolong tanaman liar belum banyak dibudidayakan dan dimanfaatkan. Tanaman ini tersebar di daerah iklim sub tropis sampai tropis tumbuh dipinggir sungai, bukit, pekarangan pada tanah yang subur. Buah terung pokak mudah mengalami kerusakan setelah dipanen karena proses respirasi oksidatif dan aktivitas enzimatis. Buah terung pokak masih belum populer di Indonesia sebagai bahan pangan. Kebutuhan pangan fungsional sangat dibutuhkan masyarakat untuk obat herbal. Masyarakat Indonesia belum banyak menkonsumsi buah terung pokak dikarenakan belum banyak diketahui sebagai bahan pangan.

Buah terung pokak potensi dikembangkan sebagai bahan pangan berfungsi untuk kesehatan tubuh karena mengandung senyawa bioaktif. Ekstraksi buah Solanum torvum dengan metanol mengandung glikosida steroid yang berfungsi antiinflamasi netrofil (6). Buah Solanum tovum mengandung seskuiterpen berfungsi sebagai imunosupresan (7). Beta sitosterol adalah senyawa kimia yang dapat menghambat beberapa jalur sinyal sel meliputi proliferasi, siklus sel, apoptosis, invasi, kelangsungan hidup, angiogenesis, dan peradangan (8). Penelitian ini bertujuan menganalisis kandungan senyawa bioaktif pada fraksi heksana terung pokak dan sifat sitotoksiknya menggunakan sel kanker payudara T47D secara invitro.

\section{METODE}

Terung pokak (Solanum torvum) diperoleh dari desa Sumber Manjing Kulon Malang sebagai tanaman liar. Buah dipilih, dibersihkan dan diproses menjadi bubuk kering menggunakan metode optimasi pengolahan respon permukaan (RSM-BBD). Hasil prediksi optimasi pengolahan bubuk Solanum torvum yang terpilih yaitu curing 5 hari, lama fermentasi 6 jam 5 menit, suhu pengeringan $50^{\circ} \mathrm{C}$ dan waktu pengeringan 14 jam pengeringan vakum. Hasilnya disimpan dalam wadah kedap sebagai bahan utama penelitian. Sel kanker payudara T47D dan Sel vero diperoleh dari koleksi CCRC (Cancer Chemoprevention Research Center), Fakultas Kedokteran UGM, Jogjakarta.

Bahan lain termasuk aquabides, metanol, etanol 80\%, n heksana (р.a.), etil asetat (р.а.), DMSO, alkohol 80\%, media RPMI, M199, Fetal Bovine Serum, penisilinstreptomisin, tripsin, EDTA, SDS, MTT, RNA-se, Triton- $\mathrm{X}$
100, propidium iodida, annexin V, timbal (II) asetat, isopropanol, kloroform, Molish, pereaksi Mayer, pereaksi Bouchardat, pereaksi Dragendroff, pereaksi LiebermannBurchard diperoleh di Laboratorium Parasitologi dan Patologi Fakultas Kedokteran Universitas Gajah Mada Yogyakarta.

\section{Kromatografi(GCMS)}

Kromatografi ekstrak dilakukan menggunakan alat Gas Chromatography Mass Spectrometer (GCMS QP 2010 SE Shimadzu) dilengkapi dengan kolom ZB-AAA $(10 \mathrm{~mL} \times$ $0,25 \mathrm{~mm} D$ Phenomenex Inc). Gas helium digunakan sebagai gas pembawa dengan laju air $0,6 \mathrm{~mL} / \mathrm{menit}$. Injeksi volume gas sebanyak $2 \mu \mathrm{L}$ dengan aio split 127,5 . Suhu diatur menggunakan program untuk kolom oven sebesar $60^{\circ} \mathrm{C}$ dengan kenaikan suhu sebesar $60^{\circ} \mathrm{C}$ hingga $220^{\circ} \mathrm{C}$ dengan tekanan konstan $15 \mathrm{kPa}$. Suhu kemudian dinaikkan menjadi $280^{\circ} \mathrm{C}$. Suhu injeksi dijaga tetap $280^{\circ} \mathrm{C}$ dengan waktu pembacaan selama 15 menit. Spektrofotometer massa dioperasikan pada mode elektron ion positif dengan energi ionisasi $70 \mathrm{eV}$. Solvent cut time diatur pada 0-2 menit. Waktu sampling data diatur 0,5 menit hingga 7 menit pada m/z 20-1000 (3,33u/detik). Persentasi relatif dari tiap komponen diketahui melalui perbandingan rerata area puncak terhadap total area. Identifikasi nama senyawa, berat molekul, dan struktur komponen dari bahan yang diuji berdasarkan data yang tersimpan dalam kumpulan data Wiley dan diolah menggunakan software Lab Solution (10).

\section{Ektraksi dan Fraksinasi Solanum torvum}

Sampel buah kering Solanum torvum 10 gram dimaserasi dalam $100 \mathrm{~mL}$ etanol $80 \%$ selama 24 jam sambil diaduk, kemudian hasil ekstrak disaring dan disimpan dalam wadah kedap. Sampel dimaserasi diulang hingga 3 kali. Hasil ekstrak etanol dipekatkan dengan rotary evaporator pada $40^{\circ} \mathrm{C}$ kemudian ekstrak dipindah ke botol steril dikeringkan dengan gas nitrogen, disimpan sebagai bahan uji.

Fraksinasi ekstrak etanol dengan heksana masing masing $50 \mathrm{ml}$ (1:1) pada corong pisah, lapisan heksana ditampung, lapisan ekstrak etanol difraksinasi hingga 3 kali. Fraksi heksana dipekatkan dengan rotary evaporator sampai kental, kemudian fraksi dipindah ke botol steril untuk dikeringkan dengan gas nitrogen dan disimpan sebagai bahan uji.

\section{Uji Sitotoksik Metode MTT}

Uji sitotoksik pada sel T47D dengan sampel uji fraksi heksana Solanum torvum kadar 31,25ppm, 62,5ppm, $125 \mathrm{ppm}$, pada ELISA reader (Bencmark Bio Rad), panjang

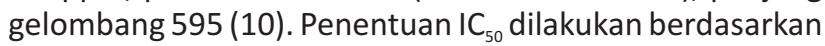
grafik dan perhitungan persamaan linier.

\section{Uji Siklus Sel dan Apoptosis Menggunakan Metode Flowcytometer}

Sel kanker payudara T47D $5 \times 10^{5}-1 \times 10^{6}$ sel/sumuran ditanam pada pelat mikro 6 sumuran, ditambah media komplit RPMI dan diinkubasi selama 24 jam pada $37^{\circ} \mathrm{C}, \mathrm{CO}_{2}$ $5 \%$. Uji penghambatan proliferasi menggunakan metode MTT dan uji apoptosis tahap dini dan akhir dilakukan sesuai standar (1). Kadar fraksi heksana terung pokak yang digunakan $36,76 \mu \mathrm{g} / \mathrm{g}$ dan $85,58 \mu \mathrm{g} / \mathrm{g}$. Pengukuran dilakukan menggunakan Flowcytometer (FACS-Calibur) (11). Sebagai kontrol digunakan sel T47D tanpa perlakuan zat sitotoksik (kontrol negatif), dan perlakuan doksorubisin

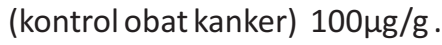




\section{HASIL}

Hasil pemisahan dan identifikasi senyawa kimia fraksi heksana bubuk terung pokak menunjukkan adanya 29 komponen kimia (Gambar 1, Tabel 1).

Tabel 1. Komponen kimia fraksi heksana bubuk terung pokak

\begin{tabular}{|c|c|c|c|c|c|}
\hline Puncak & $\begin{array}{c}\text { Waktu } \\
\text { retensi } \\
\text { (mnt) }\end{array}$ & $\begin{array}{c}\text { Indeks } \\
\text { similaritas }\end{array}$ & $\begin{array}{c}\text { Luas area } \\
\text { puncak } \\
\left(\mathrm{mm}^{2}\right)\end{array}$ & $\begin{array}{c}\text { Persen } \\
\text { komposisi }\end{array}$ & $\begin{array}{c}\text { Nama } \\
\text { senyawa }\end{array}$ \\
\hline 1 & 1,039 & 92 & 1438,79 & 8,48 & asam asetat \\
\hline 2 & 1,04 & 92 & 2137,9 & 12,61 & asam propionat \\
\hline 3 & 1,156 & 92 & 65,99 & 0,389 & 2-pentenal \\
\hline 4 & 1,16 & 92 & 768,42 & 4,53 & 2-metilfuran \\
\hline 5 & 1,163 & 92 & 328,77 & 1,93 & 1 penten 3-on \\
\hline 6 & 1,165 & 92 & 1328,54 & 7,83 & asam butirat \\
\hline 7 & 1,167 & 92 & 437,65 & 2,58 & 2-metil butanal \\
\hline 8 & 1,168 & 92 & 864,09 & 5,09 & 2.3 butanedion \\
\hline 9 & 1,203 & 92 & 132,65 & 0,78 & dimetil disulfida \\
\hline 10 & 1,20 & 92 & 437,99 & 2,58 & asam valerat \\
\hline 11 & 1,209 & 92 & 1038,65 & 6,12 & furfural \\
\hline 12 & 1,21 & 92 & 218,56 & 1,28 & 3- heksanon \\
\hline 13 & 1,22 & 92 & 547,14 & 3,22 & metional \\
\hline 14 & 1,22 & 92 & 87,55 & 0,51 & heksanal \\
\hline 15 & 1,23 & 92 & 86,77 & 0,51 & benzaldehid \\
\hline 16 & 1,23 & 92 & 143,05 & 0,84 & 2- heptenal \\
\hline 17 & 1,23 & 92 & 328,55 & 1,93 & 4- heptenal \\
\hline 18 & 1,42 & 92 & 1084,09 & 6,4 & 1,5-oktadien \\
\hline 19 & 1,43 & 92 & 759,76 & 4,48 & 2-butifuran \\
\hline 20 & 1,44 & 92 & 118,69 & 0,7 & 3,5-oktadin-2-on \\
\hline 21 & 1,52 & 92 & 218,54 & 1,28 & 1-okten-3-on \\
\hline 22 & 1,54 & 92 & 438,9 & 2,58 & 2- pentilfuran \\
\hline 23 & 1,55 & 92 & 711,54 & 4,19 & 2,6-nonedienal \\
\hline
\end{tabular}

Tabel 1. Komponen kimia fraksi heksana bubuk terung pokak (Lanjutan)

\begin{tabular}{cccccr}
\hline Puncak & $\begin{array}{c}\text { Waktu } \\
\text { retensi } \\
\text { (mnt) }\end{array}$ & $\begin{array}{c}\text { Indeks } \\
\text { similaritas }\end{array}$ & $\begin{array}{c}\text { Luas area } \\
\text { puncak } \\
\left(\mathbf{m m}^{2} \text { ) }\right.\end{array}$ & $\begin{array}{c}\text { Persen } \\
\text { komposisi }\end{array}$ & $\begin{array}{c}\text { Nama } \\
\text { senyawa }\end{array}$ \\
\hline 24 & 1,55 & 92 & 769,77 & 4,54 & 2-nonenal \\
25 & 1,62 & 92 & 68,69 & 0,40 & 2-isopropil \\
26 & 1,63 & 92 & 439,11 & 2,59 & linalool \\
27 & 2,80 & 92 & 48,79 & 0,28 & 2-isobutil \\
28 & 3,09 & 92 & 1029,65 & 6,07 & gama dekalakton \\
29 & 5,003 & 92 & 869,8 & 5,13 & B damaskenon \\
\hline
\end{tabular}

Aktivitas Sitotoksik, Penghambatan Siklus Sel, dan Induksi Apoptosis

Hasil uji aktifitas sitotoksik pada perlakuan fraksi heksana buah Solanum torvum dengan metode MTT menunjukkan $I_{50}=85,58 \mu \mathrm{g} / \mathrm{mL}$ (Tabel 2 ).

Tabel 2. Uji sitotoksik

\begin{tabular}{lrcr}
\hline Sampel Uji & $\begin{array}{r}\text { Kadar } \\
(\mu \mathrm{g} / \mathrm{mL})\end{array}$ & $\begin{array}{c}\text { Viabilitas sel } \\
\text { T47D (\%) }\end{array}$ & IC 50 T47D $^{\text {(\%) }}$ \\
\hline & 100 & 38,37 & \\
Fraksi heksana & 50 & 93,81 & \\
Solanum torvum & 25 & 97,87 & $85,58 \mu \mathrm{g} / \mathrm{mL}$ \\
& 12,5 & 98,54 & \\
Doksorubisin & 6,26 & 99,06 & \\
& 100 & 93,17 & $36,76 \mu \mathrm{g} / \mathrm{mL}$ \\
& 50 & 54,73 & (Kontrol positif) \\
\hline
\end{tabular}

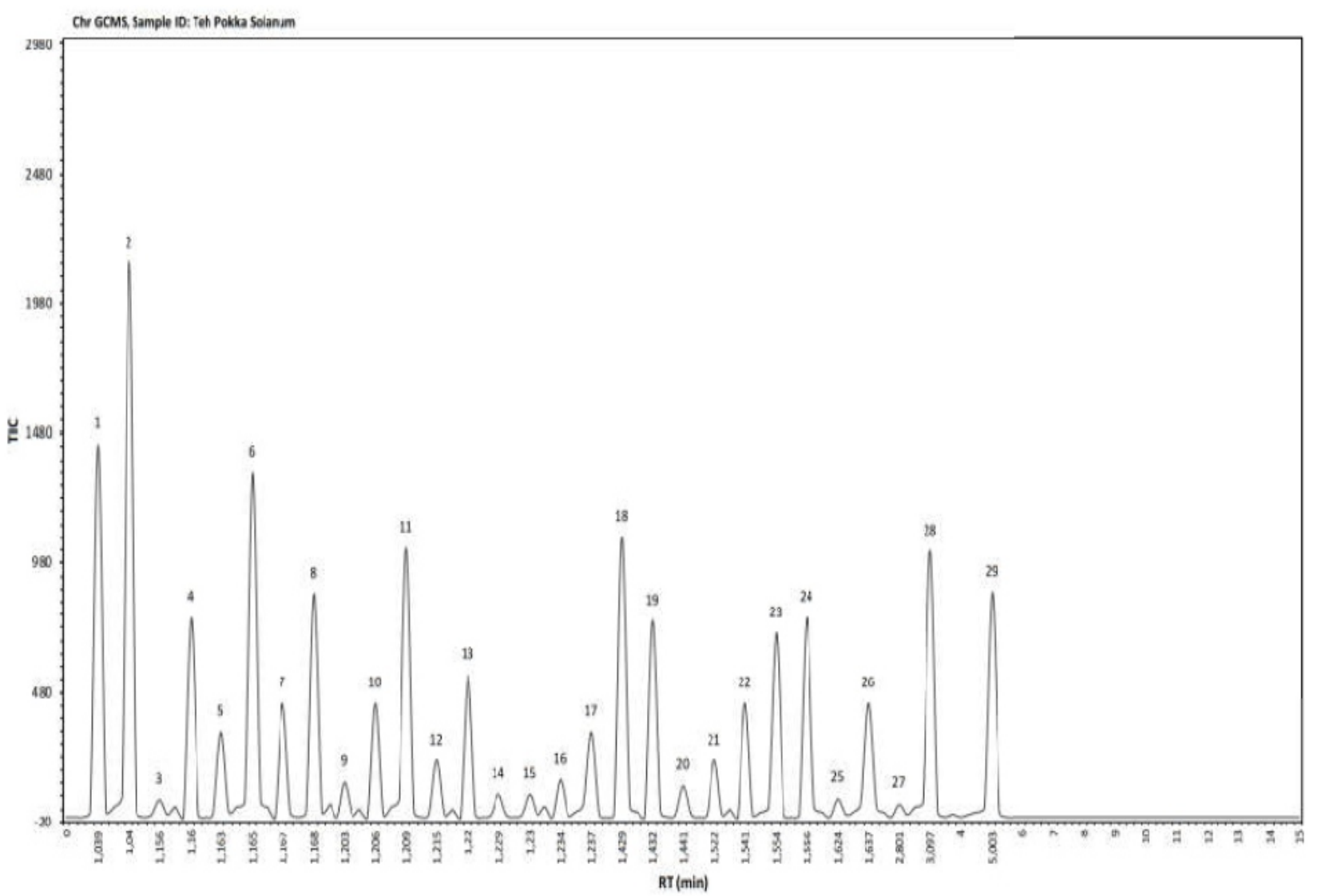

Gambar 1. Hasil analisis GCMS fraksi heksana terung pokak 
Tabel 2. Uji sitotoksik (Lanjutan)

\begin{tabular}{crrr}
\hline Sampel Uji & $\begin{array}{r}\text { Kadar } \\
(\boldsymbol{\mu g} / \mathbf{m L})\end{array}$ & $\begin{array}{r}\text { Viabilitas sel } \\
\text { T47D (\%) }\end{array}$ & \multicolumn{1}{c}{ IC 50 T47D } \\
\hline \multirow{2}{*}{ Doksorubisin } & 25 & 10,6 & $36,76 \mu \mathrm{g} / \mathrm{mL}$ \\
& 12,5 & 18,75 & (Kontrol positif) \\
Kontrol sel & 6,5 & 25,71 & \\
\hline
\end{tabular}

Hasil analisis menggunakan 20.000 sel T47D per perlakuan fraksi heksana terung pokak menunjukkan efek penghambatan siklus sel (Gambar 2, Tabel 3). Sel kanker T47D berkembang sebesar 14.100 sel (100\%), pada tahap G0-G1 sebanyak 5214 (35,84\%), tahap S sel mengalami duplikasi kromosom dan replikasi DNA sebanyak 3436 (27,05\%), dan tahap G2-M 5450 (37,46\%) sel mengalami persiapan pembelahan dan mitosis.

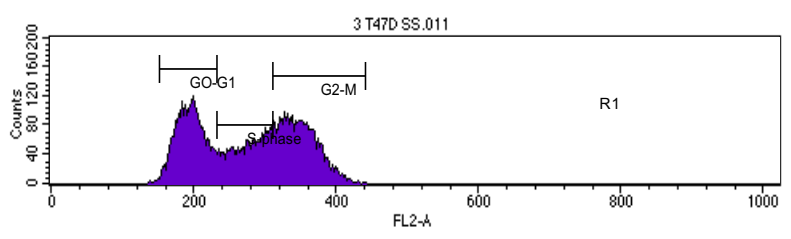

Gambar 2. Hambatan siklus sel kanker T47D

Tabel 3. Data pengamatan siklus sel T47D

\begin{tabular}{lrrrrrr}
\hline & \multicolumn{4}{c}{ Data Pengamatan Siklus Sel T47D } \\
\cline { 2 - 7 } Marker & Fraksi Heksana & Kontrol Sel T47D & \multicolumn{2}{c}{ Dokso rubisin } \\
\cline { 2 - 7 } & Events & \% Gated & Events & \% Gated & Events & \% Gated \\
\hline All & 14100 & 100 & 16080 & 100 & 14987 & 100 \\
GO-G1 & 5214 & 35,84 & 6964 & 43,29 & 6895 & 46,01 \\
S- phase & 3436 & 27,05 & 3503 & 21,78 & 3495 & 23,32 \\
G2-M & 5450 & 37,46 & 5671 & 35,26 & 4669 & 31,15 \\
\hline
\end{tabular}

Pada Gambar 2 menunjukkan fraksi heksana terung pokak dapat menghambat pertumbuhan sel kanker payudara T47D yang digunakan dalam percobaan sebesar 20.000 sel. Hasil uji siklus sel kelompok kontrol T47D (Gambar 3,Tabel 3) yaitu sel kanker payudara (kontrol sel T47D) dosis $100 \mathrm{ppm}$ dan jumlah sel T47D pada penelitian sebesar 20.000 sel. Pertumbuhan sel T47D awal sebesar 16.080 (100\%), tahap G0-G1 43,29\%, tahap S 21,78\%, tahap G2-M persiapan pembelahan sel 35,26\%.

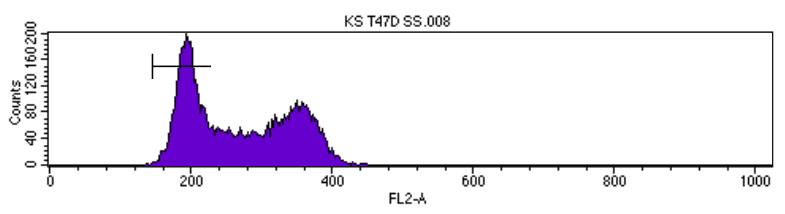

Gambar 3. Siklus sel (Kontrol sel T47D)

Siklus sel T47D yang mendapat perlakuan obat kanker doksorubisin (Gambar 4, Tabel 3) menunjukkan tahap pertumbuhan awal 14987 (100\%), G0-G1 46,01\%, tahap S 23,32\%, G2-M sebesar 31,15\% sel.

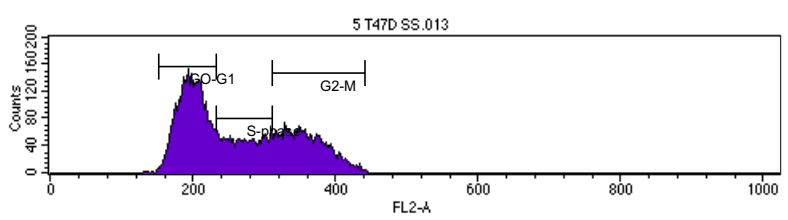

Gambar 4. Perlakuan obat doksorubisin terhadap siklus sel kanker T47D

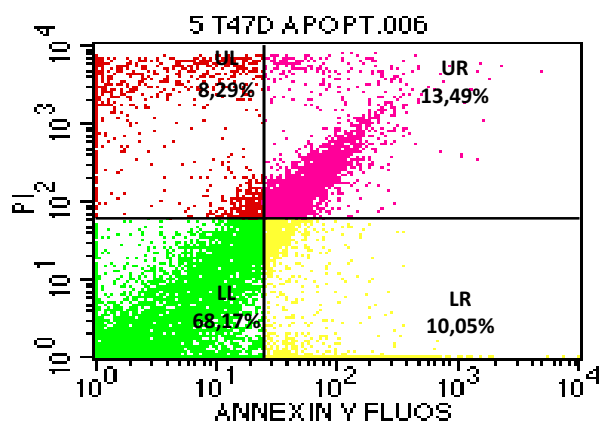

Gambar 5. Perlakuan obat kanker doksorubisin terhadap apoptosis sel T47D

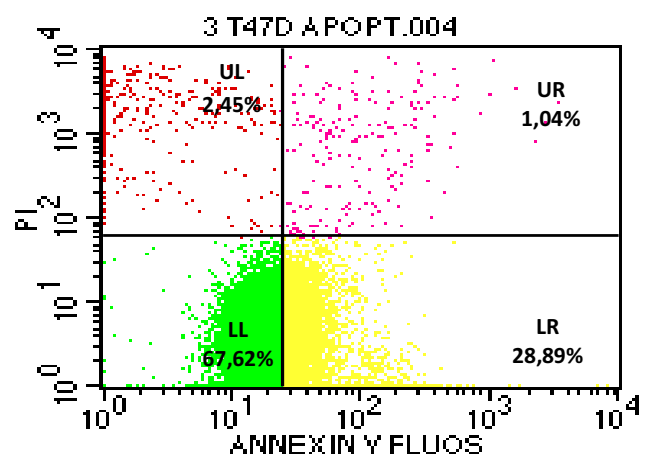

Gambar 6. Perlakuan fraksi heksana terong pokak terhadap apoptosis sel T47D

Analisis perlakuan obat kanker doksorubisin terhadap apoptosis sel kanker payudara T47D menunjukkan bahwa pada kuadran UL yaitu sel mengalami nekrosis 8,29\%, kuadran LL sel kanker hidup 68,17\%, kuadran LR yaitu apoptosis awal sebesar 10,05\%, dan kuadran UR apoptosis akhir 13,49\% dari perlakuan total sel kanker T47D sebesar 20.000 (Gambar 5). Fraksi heksana buah Solanum torvum meningkatkan apoptosis sel kanker payudara T47D (Gambar 6), nekrosis 2,45\%, sel hidup 67,62\%, apoptosis awal $28,89 \%$ dan apoptosis akhir 1,04\%, dari perlakuan total sel kanker T47D sebesar 20.000

Kontrol sel T47D yaitu pada kuadran UL sel mengalami nekrosis sebesar 2,94\%. Pada kuadran LL sel kanker T47D hidup sebesar 94,72\%, kuadran LR menunjukkan apoptosis awal 1,95\% dan pada kuadran UR sel mengalami apoptosis akhir sebesar 0,39\% dari total sel kanker T47D sebesar 20.000 . 


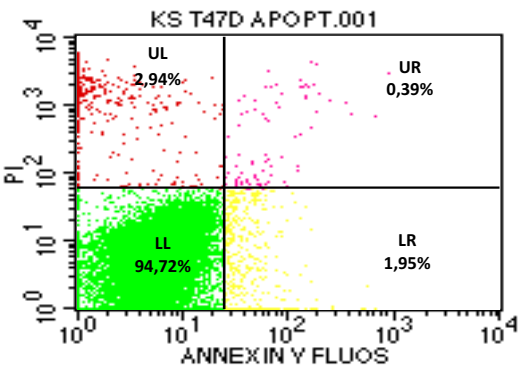

\section{Gambar 7. Perlakuan kontrol sel kanker T47D terhadap} apotosis sel T47D

Ringkasan hasil pengamatan apoptosis sel T47D dari perlakuan obat kanker doxorubicin, fraksi heksana terung pokak, dan kontrol sel T47D (Tabel 4) menunjukkan bahwa fraksi heksana terung pokak meningkatkan apoptosis awal $\sim 3$ kali lipat lebih tinggi daripada doksorubisin.

Tabel 4. Data apoptosis sel kanker T47D

\begin{tabular}{ccrr}
\hline \multicolumn{4}{c}{ Apoptosis sel T47D } \\
\hline \multirow{2}{*}{ Kuadran } & Doksorubisin & Fraksi heksana & Kontrol sel \\
\cline { 2 - 4 } & \% Gated & \% Gated & \% Gated \\
\hline UL & $8,29 \%$ & $2,45 \%$ & $2,94 \%$ \\
UR & $13,49 \%$ & $1,04 \%$ & $0,39 \%$ \\
LL & $68,17 \%$ & $67,62 \%$ & $94,72 \%$ \\
LR & $10,05 \%$ & $28,89 \%$ & $1,95 \%$ \\
\hline
\end{tabular}

\section{DAFTAR PUSTAKA}

1. Lu YY, Luo JG, and Kong LY. Chemical Contituents from Solanum torvum. Chinese Journal of Natural Medicines. 2011; 9(1): 30-32.

2. Mohan M, Kamble S, Gadhi P, and Kasture S. Protective Effect of Solanum torvum on Doxorubicin- Induced Nephrotoxicity in Rats. Food and Chemical Toxicology. 2010; 48(1): 436-440.

3. Smith SW, Giesbrecht E, Thompson M, Nelson LS, and Hoffman RS. Solanaceous Steroidal Glycoalkoloids and Poisoning by Solanum Torvum, the Normally Edible Susumber Berry. Toxicon. 2008; 52(6): 667-676.

4. Balachandran $\mathrm{C}$, Emi N, Arun $\mathrm{Y}$, et al. In Vitro Anticancer Activity of Methyl Caffeat Isolated from Solanum torvu Swartz. Fruit. Chemico-Biological Interactions. 2015; 242: 81-90.

5. Karmakar K, Islam A, Chhanda SA, Tuhin TI, Muslim $\mathrm{T}$, and Rahman A. Secondary Metabolites from the Fruits of Solanum torvum SW. Journal of Pharmacognosy and Phytochemistry. 2015; 4(1): 160-163.

6. Lee $\mathrm{CL}$, Hwang TL, He WJ, et al. Anti Neutrophilic Inflammatory Steroidal Glycosides from Solanum torvum. Phytochemistry. 2013; 95: 315-321.

7. Yuan PI, Wang XP, Jin BL, et al. Sesquiterpenes with Immunosuppressive Effect from the Stems of Solanum torvum. Phytochemistry Letters. 2016; 17: $126-130$.

\section{DISKUSI}

Pada penelitian ini ditemukan fraksi heksana terung pokak mengandung 29 komponen kimia (Tabel 1), berbeda dengan laporan lain yang menyebutkan Solanum torvum mengandung solanolakton $\mathrm{A}$ dan $\mathrm{B}$, torvosid $\mathrm{M}$ dan $\mathrm{N}$ dan saponin stereoid dan glikosida steroid yang berfungsi sitotoksik terhadap sel kanker kulit A375 in vitro dengan $I_{50} 30 \mu \mathrm{M}$ sampai dengan $260 \mu \mathrm{M}(11,12)$. Sebagai pembanding aktivitas fraksi heksana terung pokak digunakan obat kanker doksorubisin yang efektif untuk metastasis kanker payudara (13). Perlakuan pemberian obat kanker doksorubisin bersifat sitotoksik terhadap sel kanker payudara T47D dengan $\mathrm{IC}_{50} 36,76 \mu \mathrm{g} / \mathrm{mL}$ (13). Hasil penelitian ini menunjukkan bahwa fraksi heksana terung pokak dan obat kanker doksorubisin dapat menghambat siklus sel dan memicu apoptosis sel T47D. Apoptosis merupakan mekanisme untuk mengontrol proliferasi sel sebagai bagian dari proses perkembangan yang normal dan juga akan mengakibatkan kematian sel jika terdapat kerusakan DNA yang tidak dapat diperbaiki (14). Nilai batas $\mathrm{IC}_{50}$ senyawa ektrak selektif dan relevan sebagai antikanker jika $I_{50} \leq 100 \mu \mathrm{g} / \mathrm{mL}$, sedangkan untuk senyawa murni $I C_{50} \leq 25 \mu \mathrm{g} / \mathrm{mL}(15,16)$. Ekstrak dengan nilai IC ${ }_{50} \leq 100 \mu \mathrm{g} / \mathrm{mL}$ berpotensi sebagai kemopreventif (16). IC $\mathrm{C}_{50}$ doksorubisin $36,76 \mu \mathrm{g} / \mathrm{mL}$ sedangkan fraksi heksana terung pokak $85,58 \mu \mathrm{g} / \mathrm{mL}$, oleh karenanya dapat dianggap fraksi heksana terung pokak memiliki potensi antiproliferasi sel walaupun mungkin doksorubisin lebih baik.

8. Bin Sayeed MS and Ameen SS. Beta-Sitosterol: Promising but Orphan Nutraceutical to Fight against Cancer. Nutrition and Cancer. 2015; 67(8): 12161220.

9. Parthasarathy $V$ and Ajay Kumar TV. Screening of Potential GCMS Derived Antimigraine Compound from the Leave of Abrus Precatorius Linn to Target "Calcitonin Gene Related Peptide" Receptor Using in Silico Analysis. Food Science and Human Welness. 2019; 8(1): 34-39.

10. Meiyanto E, Susidarti RA, Handayani S, dan Rahmi F. Ekstrak Etanolik Biji Buah Pinang (Areca Catechu L.) Mampu Menghambat Proliferasi dan Memacu Apoptosis Sel MCF-7. Majalah Farmasi Indonesia. 2008; 19(1): 12-19.

11. Li J, Zhang L, Huang C, Guo F, and Li Y. Five New Cytotoxic Steroidal Glycosides from the Fruit of Solanun Torvum. Fitoterapia. 2014; 93: 209-215.

12. Lu Y, Luo, J, Huang X, and Kong L. Four New Steroidal Glycosides from Solanum Torvum and their Cytotoxic Activities. Steroids. 2009; 74(1): 95-101.

13. Fista EY. Uji Aktifitas Sitotoksik Senyawa 7-O-Propil 3, 4-Dimetoksik Isoflavon Hasil Sintesis pada Kultur Sel Kanker Payudara MCF -7 dan T47D. [Skripsi]. Universitas Gadjah Mada, Yogyakarta. 2014.

14. Alberts B, Johnson A, Lewis J, Raff M, Roberts K, and Walter P. Molecular Biology of the Cell. Annals of Botany. 2003; 91: 401-405.

15. Cos P, Vlietinck AJ, Berghe DV, and Maes L. Anti- 
Infective Potential of Natural Products: How to Develop a Stronger In Vitro 'Proof-of-Concept'. Journal of Ethnopharmacology. 2006; 106(3): 290-302.
16. Tsao AS, Kim ES, and Hong WK. Chemoprevention of cancer. CA: A Cancer Journal for Clinicians. 2004; 54(6): 150-180. 